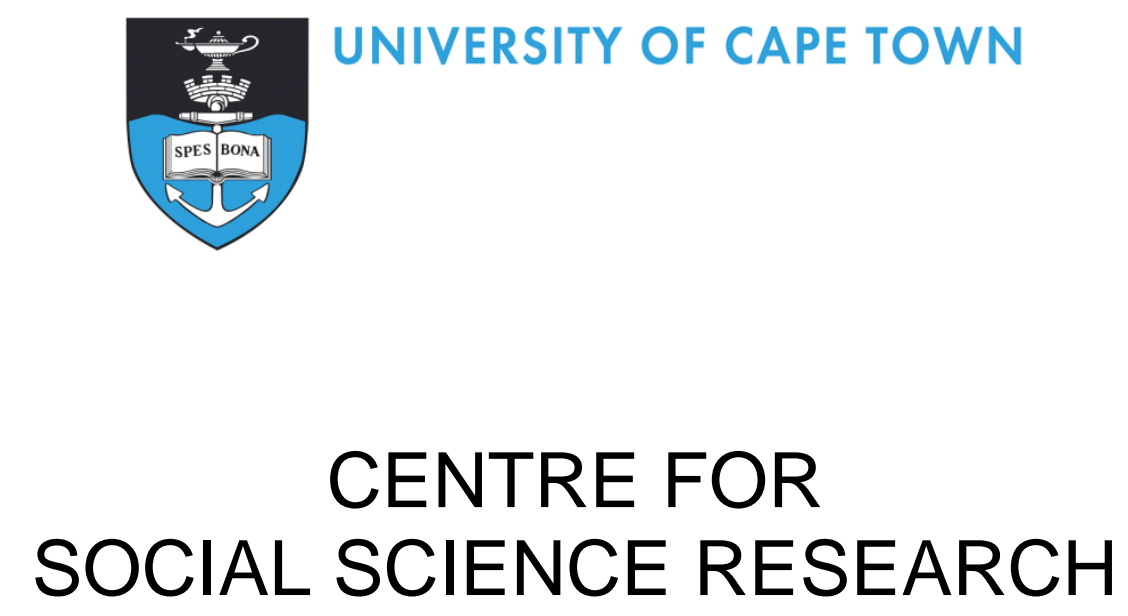

\title{
Infrastructuring Aid: Materializing Social Protection in Northern Kenya
}

Kevin P. Donovan

CSSR Working Paper No. 333

December 2013





Published by the Centre for Social Science Research
University of Cape Town
2013

http://www.cssr.uct.ac.za

This Working Paper can be downloaded from:

http://cssr.uct.ac.za/pub/wp/333/

ISBN 978-1-77011-322-0

(c) Centre for Social Science Research, UCT, 2013

\begin{abstract}
About the author:
Kevin P. Donovan is a research associate at the Centre for Social Science Research at the University of Cape Town and a Ph.D. student at the Program in Anthropology \& History at the University of Michigan.
\end{abstract}

Acknowledgments:

I gratefully acknowledge the assistance and time of my interlocutors in Kenya. Versions of this paper benefited from comments from Jeremy Seekings, Paul Edwards, and Aaron Martin. It was made possible through support from Privacy International, a Fulbright Fellowship and the Institute for Money, Technology and Financial Inclusion at the University of California, Irvine. 


\section{Infrastructuring Aid: Materializing Social Protection in Northern Kenya}

\section{Abstract}

In numerous African countries, humanitarian and development organizationsas well as governments - are expanding expenditures on social protection schemes as a means of poverty alleviation. These initiatives, which typically provide small cash grants to poor households, are often considered particularly agreeable for the simplicity of their administration and the feasibility of their implementation. This paper examines the background work required to deploy social protection in one especially remote area: the margins of postcolonial Kenya. Specifically, it documents the often-overlooked social and technical construction of the infrastructure necessary so that cash transfers may function with the ease and simplicity for which they are commended. Attention to the practice of 'infrastructuring' offers insights into the tensions and politics of what is rapidly becoming a key form of transnational governance in the global south, especially the way in which market-based means and humanitarian ethics overlap.

\section{Introduction: Infrastructures \& Infrastructuring}

Every two months, many thousands of poor Kenyans living in drought-prone areas receive around US $\$ 50$ from British taxpayers. How this money reaches the remote margins of Kenya involves bureaucratic negotiations, political commitment, and ethical ideals. But it also involves rugged trucks, Post-It notes, and carefully washed fingerprints. As these so-called 'cash transfers' become a key form of poverty alleviation in contemporary sub-Saharan Africa, this paper turns away from the high-profile battles over the politics and future of aid and humanitarianism to examine the humdrum and obscure practices that enable actually-existing poverty alleviation. In doing so, I follow Maurer (2012b) to focus on payments infrastructures - "the portals, rails and plumbing"- that move monetary value, in this case transferring it from Her Majesty's Treasury to northern Kenya (see also Elyachar, 2010). 
A growing body of interdisciplinary literature has turned to large technical systems as both objects of inquiry and objects with which it is good to think. Water supplies (Anand, 2011; von Schnitzler, 2008), oil pipelines (Mitchell, 2011), medical logistics (Redfield, 2013), and more are now firmly of interest to anthropologists and historians operating in the loose field of 'infrastructure studies.' Infrastructure is a multifaceted concept, usually defined as the sociotechnical means through which goods, people, and information circulate; infrastructures incorporate rationalities, techniques, and material objects, not to mention the labor and relations that enable those. In Edwards (2003: 185) words, "they are the connective tissue and the circulatory systems of modernity." Their absence or breakdown is thus of fundamental importance to the structure of everyday life.

In Larkin's (2013) recent characterization, the anthropology of infrastructure approaches both the "politics and poetics of infrastructure." As means of distribution and "networks of power" (Hughes, 1993), infrastructures are "constantly ranking, connecting, and segmenting spaces and people" (Larkin, 2004: 292; see also Graham and Marvin, 1996; 2001). They embody rationalities and politics (Collier, 2011) - even if the ability of any one entity to dictate their design is severely limited (Edwards et al., 2007). But as cultural anthropologists have emphasized, they also operate symbolically and aesthetically, stirring the imagination and entwining with ideology (e.g. Larkin, 2008; Barker, 2005; Humphrey, 2005; Sneath et al., 2009).

The ethnographic study of large, distributed technical systems has offered key insights into their natures and significance (Star, 1999), but also requires certain methodological sensitivities (Edwards, 2003; Ribes and Baker, 2006). For example, because infrastructure often resides in the invisible background, Bowker (1994) recommends 'infrastructural inversion,' the act of foregrounding it to investigate it more clearly. But what about regions where infrastructures do not exist as background enablers?

This paper draws on Pipek and Wulf's (2009) concept of 'infrastructuring,' by approaching ethnographically the human and material components of infrastructure 'in the making.' I draw on fieldwork in Nairobi and the north of Kenya to explicate the types of labor, negotiation, and struggle that enable functional circulatory systems in a region without infrastructural density. In particular, I emphasize the earnest desire of the humanitarian aid workers to create functional technologies, embedding them in a novel context, and having them fade into the background; for those infrastructuring, the technology was never the goal - cash assistance was - but enabling the circulation of monetary value required considerable attention to infrastructure. This effort involved negotiating breakdown through ongoing repair and maintenance (see Jackson, 
2014). In the final section of this paper, I build on von Schnitzler (2013) and Elyachar (2012b) to reflect on the political values disclosed and embodied in this type of infrastructure, suggesting it exists within two realms: the means of the market and the ethos of humanitarianism.

Developing and maintaining infrastructure is of particular consequence in subSaharan Africa. As Edwards (2003: 188) writes, the "notion of infrastructure as an invisible, smooth-functioning background "works" only in the developed world" (in addition, see Larkin, 2008). In comparison to other regions, subSaharan Africa has relatively low population densities and urbanization, as well as a large number of landlocked and poor countries. In addition to a history of colonialism, these characteristics help to account for the fact that "African countries lag behind their peers in other parts of the developing world" (Foster and Briceño-Garmendia, 2010: 1). Within the region, though, there are significant differences; while some sectors (such as ICT) have grown significantly, others (such as electricity and rural transportation) remain spartan. As the same assessment notes, "access of rural populations to infrastructure is extremely low" (22).

Table 1. Infrastructural Deficit (normalized units)

\begin{tabular}{|l|r|r|}
\hline & $\begin{array}{r}\text { Sub-Saharan low- } \\
\text { income countries }\end{array}$ & $\begin{array}{r}\text { Other low-income } \\
\text { countries }\end{array}$ \\
\hline Paved-road density & 31 & 134 \\
\hline Total road density & 137 & 211 \\
\hline Mobile phone density & 55 & 76 \\
\hline Generation capacity & 37 & 326 \\
\hline Electricity coverage & 16 & 41 \\
\hline
\end{tabular}

Source: adapted from Foster \& Briceño-Garmendia 2010: 3.

Note: Road density is measured in kilometers per 100 square kilometers of arable land; mobile density is lines per thousand; generation capacity is megawatts per million population; electricity coverage is percentage of population.

Kenya, too, has seen considerable growth in telephony, with 90 percent of the population receiving mobile coverage. However, power remains limited and the transportation infrastructure is "heavily concentrated in the southern half of the country, along the corridor linking Mombasa to Nairobi and then on to Kisumu and into Uganda" (AICD 4). The northern portion of the country-where I conducted my fieldwork-is "sparsely populated and characterized by fragmentary infrastructure coverage" (AICD 4). 


\section{Cash Transfers: Kenya and Beyond}

The history of humanitarian and development interventions in Kenya is, of course, mottled, driven by a volatile mix of donors, politicians, bureaucrats, and recipients. In recent years, the government and major donors such as the World Bank and the UK's Department for International Development (DfID) have begun to invest in "social protection" schemes known as cash transfers. This method of aid has grown dramatically: a survey conducted in 2009 found 123 cash transfer programs in sub-Saharan Africa (Garcia and Moore, 2012). These initiatives provide small to medium cash grants to poor and vulnerable populations, with some requiring that specific conditions are met (such as school enrolment or vaccination for children), while others are unconditional. As leading proponents enthusiastically sum up, the mantra is "just give money to the poor" (Hanlon et al., 2010).

The genealogy of these forms of aid is mixed. In some cases - such as South Africa (and some surrounding countries) - they "reflect... a classic 'northern' conception of desert" (Seekings, 2008: 33) which provide socialized assistance to those populations unable to meet their own needs (e.g. the elderly, the infirm, and children). As Ferguson (2010) points out, in places like Kenya the precursor is more humanitarian than welfarist. In many cases, cash transfers are replacing older forms of food aid, with even the World Food Program in Kenya experimenting with cash instead of calories. But as I discuss below, while humanitarian in origin, program officials have aspirations for institutionalizing cash transfers as rights-based social welfare, and these aspirations are directly influencing their infrastructural design in the present.

In Kenya, there are two large-scale and three smaller cash transfer programs, each operated and funded by a mix of government, donors, NGOs, and even private industry. From 2005 to 2010, spending on social protection grew from KSh 33.4 billion to 57.1 billion (from about US $\$ 367$ million to $\$ 628$ million), equivalent to 2.28 percent of GDP (GoK 2012). ${ }^{1}$ The two major programs are the Orphan and Vulnerable Children (OVC) program and the Hunger Safety Net Program (HSNP). The OVC program provides KSh 2,000 (US \$22) to 412,470 beneficiaries every two months. The HSNP - discussed in this paper - is targeted at "chronically food-insecure, extremely poor, and vulnerable people" in the arid and semi-arid lands, largely in the north of Kenya. Three other programs are much smaller in scale. The Older Persons Cash Transfer had

\footnotetext{
${ }^{1}$ At the time of my fieldwork, the Kenyan Shilling was worth about .011 US Dollars. I provide approximate conversions where applicable.
} 
33,000 beneficiaries by 2010 , and a Disability Grants program and Urban Food Subsidy reached 2,100 and 5,150 beneficiaries, respectively.

The appeals of cash transfers are multiple. A decades-old critique of food aid, most prominently espoused by Amartya Sen and Jean Dreze, has recently become more broadly acknowledged. As Dreze and Sen (1991) demonstrate, importing foodstuffs tends to undermine local farmers, leading to long-term decay in productive capacity. Furthermore, advocates of cash transfers argue that aid beneficiaries often need assets beyond food. Cash, as a fungible medium of exchange and durable store of value, offers a more permissive type of aid, not likely to spoil like food. In the case of the HSNP, the shift to cash occurred after a realization that 60 percent of the population had relied on 'emergency' food aid for more than 10 years. "Although aid was emergency based, the hunger was predictable, and many believed that it could be addressed using regular" cash transfers (Garcia and Moore, 2012).

Finally, proponents of cash transfers suggest that they are a more feasible form of aid, less likely to result in failure. For example, Samson et al. (2011) write that "In many ways, cash transfers require less government bureaucracy and administrative resources than other mechanisms for social delivery. The option of administratively feasible and affordable social transfers makes it easier for governments to consider implementing direct income support for the poorest." Importantly, technology is key to this vision. Hanlon et al. (2010: 145) say "[n]ew technology is transforming the administration of cash transfers, making it practical in even the poorest countries" and the World Bank reports that early signs suggest "new leapfrog technologies" including biometric identification can "overcome challenges that are relatively unique" to sub-Saharan Africa (Garcia and Moore, 2012: 7).

Similar arguments appeared throughout my fieldwork, such as the recognition that cash was more feasible and affordable than food: "A bag of $90 \mathrm{~kg}$ maize would cost, like, over KSh 10,000 [\$110] for it to be transported from Mombasa to [Turkana in the north]. Then, if perhaps [a beneficiary] is supposed to get a 2 kilogram container of maize, he may end up getting 500 grams because the rest has [disappeared]." 2 Others told me that "technology has been a great enabler to create an efficient institution" capable of delivering grants in rural areas. ${ }^{3}$

Despite this general consensus, the ability to deliver cash to the vulnerable and poor populations in Kenya still requires a considerable investment in institutional and infrastructural innovation. Perhaps no one recognizes this as

\footnotetext{
${ }^{2}$ Informant \#12.

${ }^{3}$ Informant \#2.
} 
much as those members of government, industry, and civil society that manage the Hunger Safety Net Program (HSNP). Since 2008, HSNP has provided cash transfers in the arid and semi-arid lands of Kenya. According to some estimates, by 2012 , the program reached nearly 400,000 beneficiaries in the historically drought-prone and impoverished counties of Mandera, Wajir, Marsabit, and Turkana. Turkana, where I conducted fieldwork in and around the capital of Lodwar in 2013, is indicative of the region, with more than 90 percent of the population below the poverty line, many of who are engaged in pastoral livelihoods dependent upon weather (GoK, 2012).

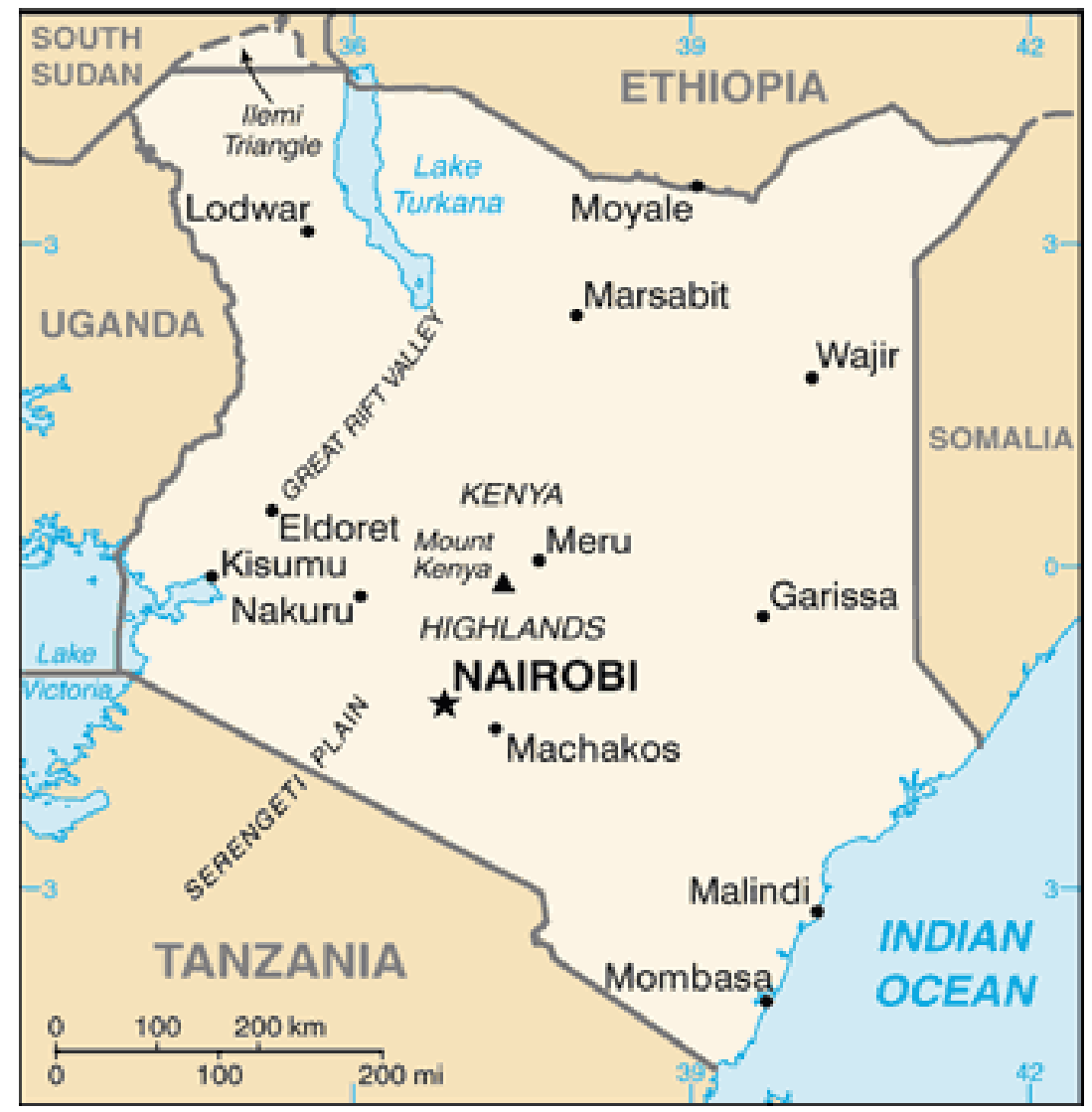

Source: Wikipedia

\section{Figure 1. Map of Kenya}

HSNP is a partnership with the government of Kenya, funded largely by the UK's Department for International Development (DfID), and with various nonprofit humanitarian organizations such as Oxfam, World Vision, Save the Children, and HelpAge International managing various components. Importantly, payments are managed by one of Kenya's largest private financial service providers, Equity Bank, selected for its ability to manage such a volume of cash dispersals and having existing access to payments technology. At the start of the HSNP, qualifying households received KSh 2,150 every two months 
(\$24), but due to inflation and drought, it has incrementally been raised to KSh $4,600 .{ }^{4}$ Due to positive assessments, the governments and donors have agreed to continue and expand the program, a process I witnessed during fieldwork.

With their focus on building the means of transfering cash, the HSNP team bears similarities to other social protection programs. In Africa and elsewhere, a variety of methods have been used to deliver cash grants, including fixed paypoints, truck-mounted ATMs, and mobile phones. Institutionally, most efforts have been run through state-owned banks or post offices, private financial institutions and payment companies, or third-party agents (such as in the case of HSNP).

Table 2. Cash distribution systems in sub-Saharan African cash transfers

\begin{tabular}{|l|r|}
\hline Cash Distribution Method & Percent \\
\hline Local office or bank & 63 \\
\hline Paypoint & 35 \\
\hline Mobile ATM & 14 \\
\hline Direct deposit & 12 \\
\hline Community committees & 9 \\
\hline Mobile phones & 7 \\
\hline Other & 5 \\
\hline
\end{tabular}

Source: Garcia and Moore, 2012: 107.

Note: Sample of 57 programs whose distribution mechanism could be determined. Some used more than one method.

Proponents and designers of cash transfer programs emphasize that the choice of payment mechanism must reflect the capacities and constraints of the program, such as population density, electric and mobile coverage, and security conditions (see Samson et al., 2011: 189-222; Porteous, 2009). For example, in South Africa and Namibia, mobile ATMs are used to reach rural communities, but administrative offices may remain distant, necessitating lengthy and expensive trips. In Lesotho "a collaborative arrangement among the post office, the Lesotho Defence Force and the Lesotho Mountain Police [uses] military helicopters to access remote areas" (Samson et al., 2011: 203). In Ethiopia's Productive Safety Net Project, 1.2 million beneficiaries are paid predominantly at government municipal offices. Earlier efforts to use vouchers and coupons (instead of cash) were found to be limiting because not enough traders accepted them; in some cases recipients needed to sell the vouchers at a discount in order

\footnotetext{
${ }^{4}$ Further information is available on their website, http://www.hsnp.or.ke/
} 
to obtain cash (Hanlon et al., 2010: 149). Another assessment found that one in three beneficiary households needed to sleep away from home due to the distance to the paypoints (Gilligan et al., 2009).

In an effort to extend access and ensure accountability, an increasing number of programs are shifting to smartcards, most visibly India through its Aadhaar program which aims to provide a universal biometric ID to be used in welfare programs. This follows an earlier initiative by the Andhra Pradesh government to similarly make payments under the National Rural Employment Guarantee Program (Johnson, 2008). Elsewhere, initiatives have partnered with existing businesses to improve accessibility: in Brazil, two-thirds of cash payments in the Bolsa Familia program are made at lottery shops (Hanlon et al., 2010: 148).

According to the World Bank, middle-income countries tend to have more "established programs expected to continue indefinitely" whereas low-income and fragile countries more frequently have short-term, emergency cash transfers, often operated by donors (Garcia and Moore, 2012: 4). Their infrastructure reflects such differences, with wealthier countries operating cash transfer programs that "typically cover a wide range of vulnerable groups and a significant portion of the population" relative to the others. In this regard, Kenya's HSNP and OVC projects are unusually ambitious for a low-income country. Their respective goals of reaching 40 percent of the poorest households in targeted districts and 50 percent of extremely poor orphans and vulnerable children make the infrastructural efforts even more interesting.

\section{Of Banks, Biometrics \& Barazas: Establishing Payments Infrastructure in Northern Kenya}

“We have issues, much issues. From training to hardware." - Informant \#10

A primary purpose of infrastructure is to enable circulation; where infrastructure is sparse or faulty, even the simple act of dispensing cash is infeasible. At the broadest level, HSNP needs to move monetary value from the British treasury to the pockets of thousands of poor Kenyans, but the real difficulty occurs within Kenya, in the effort to directly reach beneficiaries. To 'just give money to the poor' actually requires multiple infrastructures, including those to move aid workers, money, and the identities of recipients. 

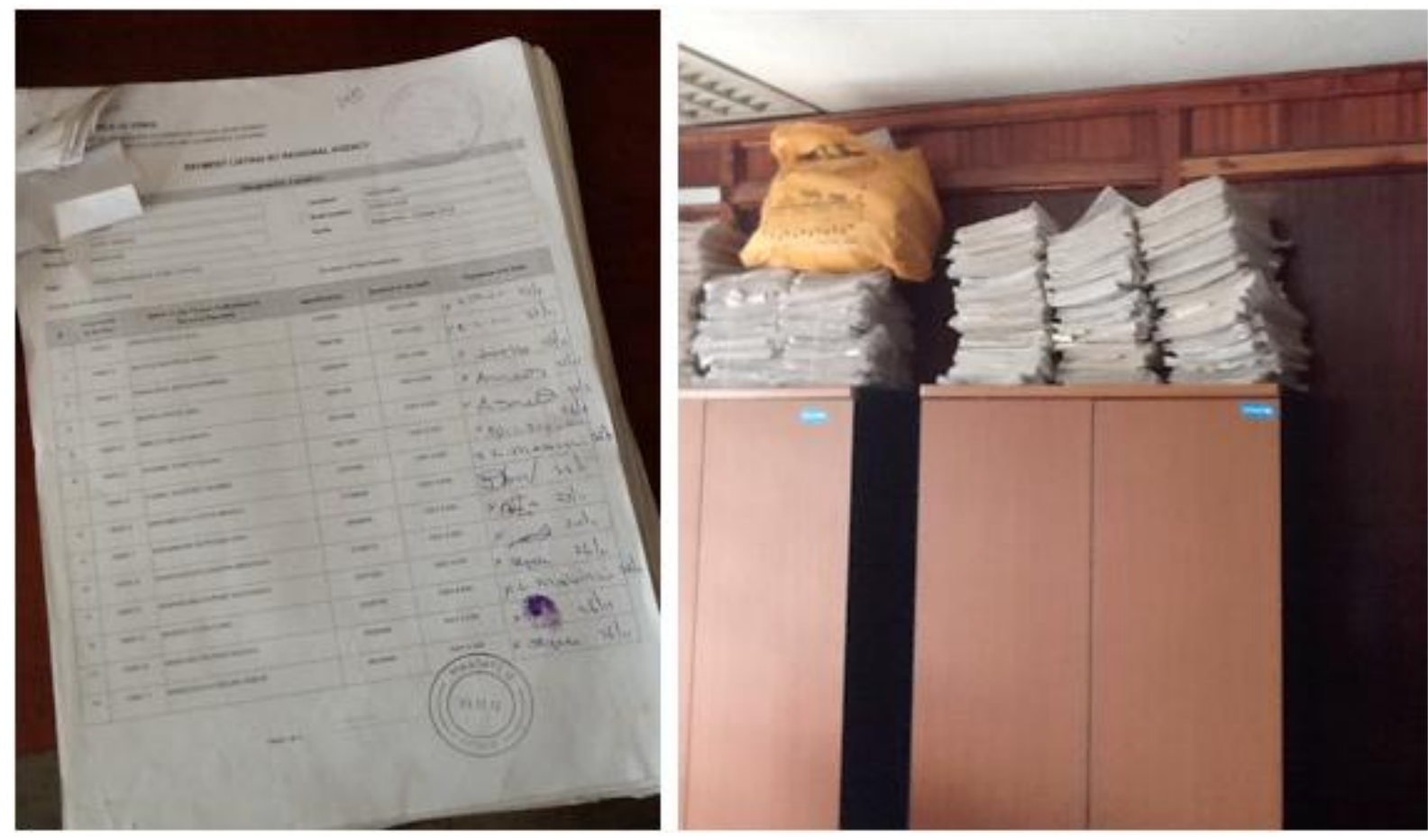

Figure 2. Paperwork to manage the OVC.

Doing so is not straightforward, and even within Kenya's social protection sector there are a variety of means of payment. Consider the Orphan and Vulnerable Children (OVC) program that reaches more than 400,000 beneficiaries as of 2010. The OVC has traditionally relied on the parastatal Postal Corporation of Kenya (PCK) to dispense physical cash at its network of 471 branches. To identify recipients, the staff in Nairobi prints in triplicate the names of beneficiaries. ${ }^{5}$ A copy is transported by vehicle to each PCK branch where recipients queue on appointed days, present their identity card, and either sign or provide an ink fingerprint to acknowledge receipt. From the beginning to successfully distributing the printed payrolls can take two weeks alone. As one OVC official told me, gesturing to bookcases overflowing with reams of paperwork, "all those bureaus, it's a lot of work... it's hard work." The unwieldy paper books are then returned and stored at the OVC headquarters. There, "our finance guy," as he was known, "has to look through all those papers to reconcile." "This tedious process of data entry eventually results in a digital record of who has (supposedly) been paid and who has not.

Numerous social protection professionals described the system as archaic and uncertain. The PCK lacks up-to-date technology such as access to the national payment system or digital cash registers. Because financial reconciliation occurs

\footnotetext{
${ }^{5}$ On paperwork, materiality, and bureaucracy, see Hull (2012).

${ }^{6}$ Informant \#10.
} 
manually, I heard frequent worries about the potential for fraud and leakage: "You see, with the manual payroll, somebody can take your ID, present himself or herself with the PCK, and get the money." Despite these worries, the partnership with the PCK was considered a marked improvement upon a previous iteration that relied on local chiefs in rural areas to distribute envelopes of cash - a practice unsurprisingly marked by bias and patronage. And although both the head of the OVC and a World Bank representative suggested they were decently assured of the current systems reliability, the potential of fraud had motivated a shift toward an electronic payments infrastructure that used biometric fingerprinting to identify recipients. "With the biometric enrolment," I was told, "it's only your fingerprints, your "bios' that can access your money."

Electronic payments that used biometric authentication are at the core of the Hunger Safety Net Program, as well. When HSNP was inaugurated in 2008, the OVC system of paperwork, identity cards, and the Postal Corporation was deemed infeasible. At one level, the reason is straightforward: the PCK is not meaningfully present in the arid and semi-arid lands. As one of the program's designers frankly told me, "pastoralists don't receive mail." 9 There were 17 PCK branches in the entirety of the four HSNP counties, an area of more than 220,000 square kilometers. Of these, many were not connected to a mobile network and in poor physical condition. Concentrating payments in these locations would not only be inconvenient for recipients, it could mark the locations as prime targets for criminals due to the volume of cash.

How to proceed without the PCK, though, was less clear, so the HSNP pioneered a new payments infrastructure with two key innovations: biometric identification and banking agents. In this system, recipients' fingerprints are scanned at enrolment and then used to identify them when they travel to local shopkeepers who were appointed as HSNP payment agents. The next three sections detail the efforts to create a functional payments infrastructure through particular attention to identification, enrolment, and payment agents.

\section{Identification}

"[Beneficiaries are] illiterate and we felt that it would be difficult to obtain signatures or for them to remember PIN numbers etcetera." - Informant \#3.

\footnotetext{
${ }^{7}$ Informant \#10.

${ }^{8}$ Informant \#10.

${ }^{9}$ Informant \#3.
} 
As scholars like Mosse (2004), Rottenburg (2009), Jensen and Wintheriek (2013) and others have described, the imperative to audit aid programs is influential, encouraging meaningful changes in everyday practice (on audit generally, see Power, 1997). ${ }^{10}$ In the case of cash transfers in Kenya, one of the chief means of accountability is the creation of identification regimes that seek to block fraud, dissimulation, and errant payments. ${ }^{11}$ Identification is important at two crucial interactions: enrolment into the HSNP when personal information is gathered and at payment when eligible individuals receive their grant.

However, governments in both colonial and post-colonial Africa have historically invested little in such identification schemes (Szreter and Breckenridge, 2012), and in Kenya many lack reliable identification documents. Because births often go undocumented, the 'documentary chain' is never started, thus making it more difficult to acquire documents later (Setel et al., 2007). ${ }^{12}$

Around 2008, when Phase I of HSNP began, reportedly 15-20 percent of adults in the program areas lacked national IDs. For those that did have an ID, it was often tattered, damaged, or out of date. Negotiating the bureaucracy to acquire an ID was difficult, could take up to a month or more, and would incur a KSh 100 fee (or KSh 300 for a replacement). Women may not have IDs because their husbands managed bureaucratic affairs, but given the more general lack of need for identity cards, many Turkana simply did without. As one program office told me, "no one is going to stop you in the middle of the desert and ask where is your ID." "13 Yet, for both programmatic accountability and because of so-called 'know your customer' financial regulations, identification of beneficiaries was crucial.

HSNP reacted to the challenge of identification at enrolment and payment in two manners. One of the partner organizations, HelpAge International, was responsible for advocating locally on behalf of those without identity cards. Their effort was assisted in the lead-up to the national election in early 2013 where ID cards were made free and registration was promoted through a "huge push" in order to boost voting. ${ }^{14}$ By 2013 , the situation had thus changed, with

\footnotetext{
${ }^{10}$ It is worth noting that some audit occurs locally, such as community validation of agents or beneficiaries stopping any robbery of the program. HSNP officials mentioned such practices during my fieldwork, but as this paper concerns infrastructure's ability to increase action at a distance, local audit is secondary.

${ }^{11}$ For a similar audit imperative and biometric response in South Africa, see Donovan (2013).

${ }^{12}$ In such cases, community elders are asked to vouch for the veracity of undocumented individuals' claims to Kenyan birth.

${ }^{13}$ Informant \#3.

${ }^{14}$ Informant \#2.
} 
far more Turkana having the national ID that was required to enroll in HSNP. ${ }^{15}$ In addition to enabling receipt of the cash transfers, some people told me that acquiring an ID removed local forms of dependency for those who previously relied on ID-wielding third parties to act on their behalf. ${ }^{16}$



Figure 3. A silhouetted photo shows that identity cards do not necessary imply identification.

While a national ID was a key component of HSNP enrolment, payment required a means of authenticating identity that was considered suitably secure and reliable. Identity cards were not likely to last long enough, it was felt, or may also lead to forms of dissimulation such as using another person's card. Thus, during enrolment, HSNP collected digital fingerprint scans of beneficiaries that were then used to verify individuals before each payment. As a major donor official related, "I think as institutions and as a government, there has to be a case for secure payments. We need to provide a reasonable level of assurance that the right people are being paid the right amounts, in the right time, in a secure fashion. And I think for us and some of our partners... the push has generally been for biometrics and for electronic payments because, at the moment, those are some of the most secure, to our minds' knowledge, means of paying beneficiaries." $" 17$

\footnotetext{
${ }^{15}$ In some cases, child-headed households (who lack a member old enough to qualify for a national ID) needed to be accommodated in an ad hoc manner, giving literal evidence to Star's (1991) discussion of infrastructural orphans.

${ }^{16}$ Informant \#3.

${ }^{17}$ Informant \#8.
} 
Adopting biometric identification, however, is not without its downsides. For one, digital fingerprinting is a relatively untested technology, prone to failure (Magnet, 2011), especially in places like northern Kenya. It tends to be expensive: the biometric authentication device costs around KSh 50,000 (\$550) and the cost per transfer is nearly double some alternatives. Biometric payments infrastructure is also proprietary, meaning it does not interoperate with normal ATMs, shops' devices, and the like.

Instead of biometrics, HSNP could have adopted personal identification numbers (PINs), just like those used in debit cards around the world. PINs are standard, well tested, and considerably less expensive, yet they were rejected for reasons that reveal much about the rationalities operating within this particular humanitarian intervention.

There were two key attributes of biometric identification that HSNP officials found compelling in their quest for "a reasonable level of assurance". First, it individualizes identification because of the uniqueness of each person's fingerprints. ${ }^{18}$ Individualizing cash payments was important for HSNP officials who spend considerable time and effort determining who qualifies for support. Program administrators were concerned that sharing PINs would enable others - whether wayward family members or unscrupulous shopkeepers-to defraud beneficiaries, thus undermining the program's goals.

The second reason for rejecting PINs was considered more important. Almost universally, when I would ask why not use PIN authentication in the HSNP, I was told it was because recipients were "illiterate." "Even writing down a PIN and keeping it secure, I was told, "can be a challenge for pastoralists" who lack "desks or drawers or anywhere where they can keep some of these documents." " Biometric identification, on the other hand, absolves the need to remember a PIN by affixing the means of identification to the material body (van der Ploeg, 2002); it was thought, then, that it would remove the need for elderly beneficiaries to rely on a PIN-savvy assistant. HSNP recipients cannot, as one person put it, "forget their thumb." ${ }^{20}$ Thus, it was quite explicitly a particular understanding of the intellectual (in)capacity and material culture (or lack thereof) that informed the adoption of biometric identification by HSNP.

\footnotetext{
${ }^{18}$ However, see Cole (2006) for a caution.

${ }^{19}$ Informant \#3.

${ }^{20}$ Informant \#3.
} 


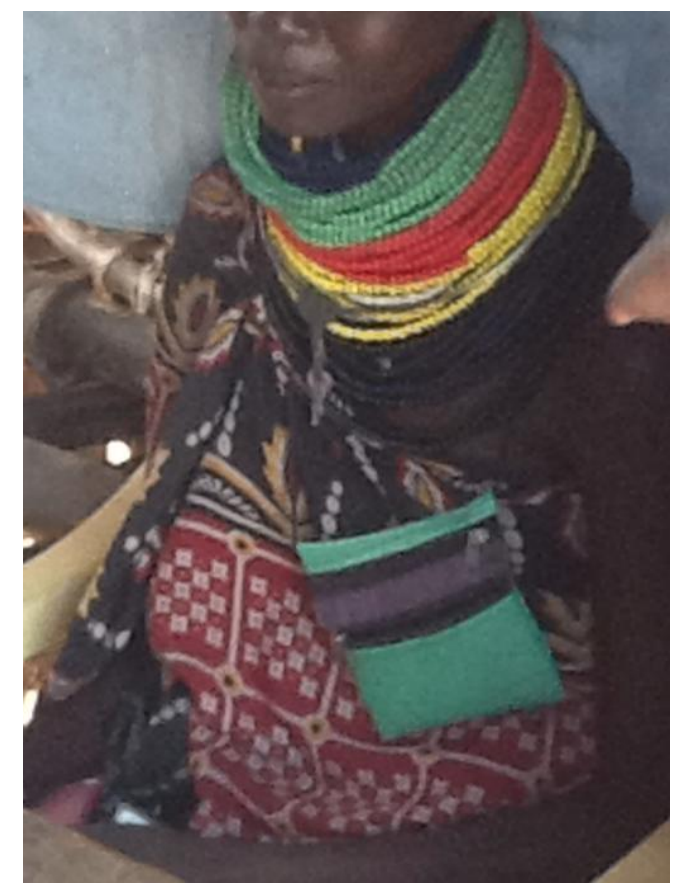

Figure 4. Without "desks or drawers", key documents are kept on the person.

Neither conception is prime facie wrong - and at least some HSNP recipients did prefer not to have to remember a PIN; yet, the belief that illiteracy prohibits PIN authentication is curious. For one, remembering a four or five digit number would not seem to be a matter of literacy; it should not even be a matter of numeracy, as it does not require any math. Secondly, Kenya is now well known for the success of mobile money services like M-PESA, including amongst poor and illiterate populations (Maurer, 2012a; Donovan, 2012). More than 15 million M-PESA users manage to use a PIN for each transaction. A more accurate consideration would rather note that HSNP cards are used less frequently than mobile money accounts, thus heightening the chance of forgetting a randomly assigned string of numbers. Furthermore, due to technical reasons set by distant financial corporations, resetting a forgotten PIN is a difficult and time-consuming endeavor in rural areas due to the requirement to re-issue a new physical card along with a new PIN.

Affixing identification to the material body, however, caused complications. HSNP needed to allow beneficiaries to nominate a secondary recipient whose fingerprints would also be accepted for payment. This was because some beneficiaries are unable to travel to payment agents and because apparently around one percent of beneficiaries are consistently unable to use biometrics due to damage to their fingerprints (such as from age, manual labor, and smoking). Additionally, over time fingerprints reportedly became damaged, such as 
through a game that the Turkana people play in the sand. ${ }^{21}$ Even this small percentage has proven "a fairly big problem" according to one donor official, and those in charge of handling HSNP complaints and grievances told me that the "majority of the complaints we receive through the grievance system is because people can't access their money through the card because of the fingerprints." 22 To overcome this type of exclusion, HSNP permitted a secondary recipient to be registered, oftentimes a family member who would withdraw cash for the actual recipient. As I was told, "On humanitarian grounds, even one exclusion is too much." ${ }^{23}$ The dual recipient structure of HSNP did permit some form of access to those unable to use biometrics, but it also introduced a form of dependency, with some reported cases of the secondary recipient taking advantage of their dependent.

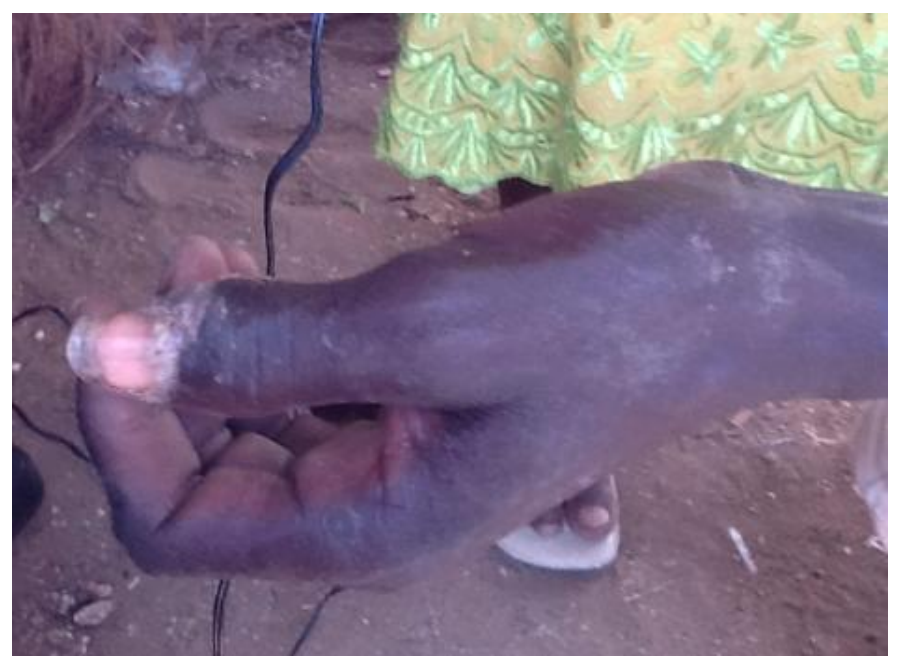

\section{Figure 5. Manual labor can make fingerprints difficult to scan.}

These challenges demonstrate how biometric technology "scripts" reality, a phrase Akrich (1992) uses to represent the manner in which technologies "necessarily make hypotheses about the entities that make up the world into which the object is to be inserted." The standards that infrastructures embody allow action at a distance, but this is not always equal access, troubling the humanitarian ethos of "even one exclusion [being] too much."

For humanitarian organizations adopting biometric technology, there are at least three assumptions built into biometric technology. It assumes mobility because it requires the person to be present for its use (unlike a PIN which can be shared). ${ }^{24}$ It assumes corporeal stability through its failure to recognize that

\footnotetext{
${ }^{21}$ Informant \#12.

${ }^{22}$ Informant \#5.

${ }^{23}$ Informant \#14.

${ }^{24}$ On the potential desirability of this in a similar context, see Mas (2012).
} 
fingers deteriorate (with age and through temporary abrasions). And it assumes uniformity by assuming all people are equally able to provide fingerprints even though a meaningful proportion is incapable of doing so. ${ }^{25}$ This echoes Burrell's discussion in Ghana of how many information technologies now being used in sub-Saharan Africa are not designed for such "invisible users." This ill-fitting script therefore requires the dynamic of mutual orientation that Akrich (1992) describes, whereby adjustments are made (or fail to be made) between the user and technology.

Further difficulties of mutual orientation between users and infrastructure are illustrated by the case of enrolment in biometric identification. In addition to its individualizing capacity, fingerprinting has been favored because of its presumed universality; unlike "literacy" or the capacity to remember a PIN, everyone can present their finger, HSNP's designers reasoned. Equity Bank's director of technology told me that "some of the people targeted are not numerate or sometimes you can be illiterate. And the biometric removes that indignity of having someone carrying a PIN because everybody is able to be served... it's all part of the dignity thing." 26

But achieving universality is less straightforward than often assumed. In some cases, would-be beneficiaries were suspicious of biometric technology (not to mention the novel idea of free money). Within the ethnic Somali population in northeast Kenya this was prompted by worries that HSNP was "capturing these details to share with the Americans" or "convert them to Christians". ${ }^{27}$ In other instances people worried that the information would be shared with the police for criminal investigations. ${ }^{28}$ These admittedly rare instances of hesitation were usually overcome through a process of "sensitization" - as the HSNP officials called it. Through convening barazas (Swahili for community gathering), HSNP representatives explained the program and the technology. Here, they particularly valued the support of chiefs in gaining the public's acceptance, demonstrating the need for infrastructure to rely on interpersonal trust and authority, as well as technical efficacy. ${ }^{29}$

\footnotetext{
${ }^{25}$ For the discriminatory aspects of other surveillance technologies, see Lyon (2003).

${ }^{26}$ Informant \#2.

${ }^{27}$ Informant \#11.

${ }^{28}$ Informants \#3 and 11.

${ }^{29}$ As Star (1999) has emphasized, infrastructure is learned as part of a community of practice.
} 


\section{Enrolment}

This social act of building goodwill and trust was followed by enrolment, during which the technology proved far more intransigent than the beneficiaries. The international humanitarian organization Oxfam largely conducted enrolment and allowed me to observe their work in 2013 when they were registering beneficiaries for HSNP's expanded Phase II. This was an enormous task, involving traveling more than 400 kilometers in some cases to register more than 99,000 households (or more than 600,000 individuals). Registering one individual could take more than 10 minutes in some cases. Because of the risk of future drought, HSNP hoped to register all residents to enable rapid expansion in the future. "The idea," I was told, "is to have a database so that when we do have some element of an emergency, some sort of shock, we don't have to start going in to register everybody from scratch." ${ }^{30}$ In this way, expectations of the future were being embedded in the present-day act of infrastructuring.

To do so, they used teams of mobile registrars composed of young Oxfam employees from the region. Although they did not share the dress or lifestyle of the largely pastoral communities they enrolled, these aid workers did know the local language and have a better understanding of local practices and customs. Given the vastness of Turkana, the shoddy transportation infrastructure, and the time it takes to enroll beneficiaries, it was impossible for the teams to return to the district capital of Lodwar each night. Instead, they operated on twenty-day shifts, camping near the villages they were registering. In one case I observed, they had set up their tents inside unused classrooms and were thankful for the only concrete buildings when an unseasonable rainstorm swept through.

These aid workers were active infrastructurers, building the means through which cash could ultimately circulate. But in doing so, they relied on existing infrastructure like the school buildings or rugged SUVs. As with the Médecins sans Frontières teams that Redfield (2013) documented, Oxfam relied on Toyota Land Cruisers, ubiquitous within humanitarian work, to traverse extended distances through which there were no paved roads. ${ }^{31}$ These vehicles are rugged enough to be quasi-independent of roads and also standardized enough to be easy to repair. It is hard to imagine establishing a cash transfer in remote Turkana without them, but while SUVs permit humanitarianism where roads are lacking, they are also a structuring, hierarchal agent. One of the everyday realities of Turkana is contending with fragmented, decrepit infrastructure (cf. Larkin, 2008) but the functionality of the Land Cruiser allows those with access

\footnotetext{
${ }^{30}$ Informant \#5.

${ }^{31}$ Given the incapacity to repair paved roads in Turkana, dirt paths were actually preferred to once-paved roads, now riddled with potholes - except when it rains.
} 
to move about more fluidly. As Smirl and Lister (2010) argue, being in a car produces an affect of speed, placelessness, and separation. It positions the aid worker (or visiting ethnographer) as more secure - even more dangerous - as the vehicle hurdles though the bush where goats and their young herders roam. Infrastructured space is manageable space (Dourish and Bell, 2007), but only for those with access to the infrastructure.

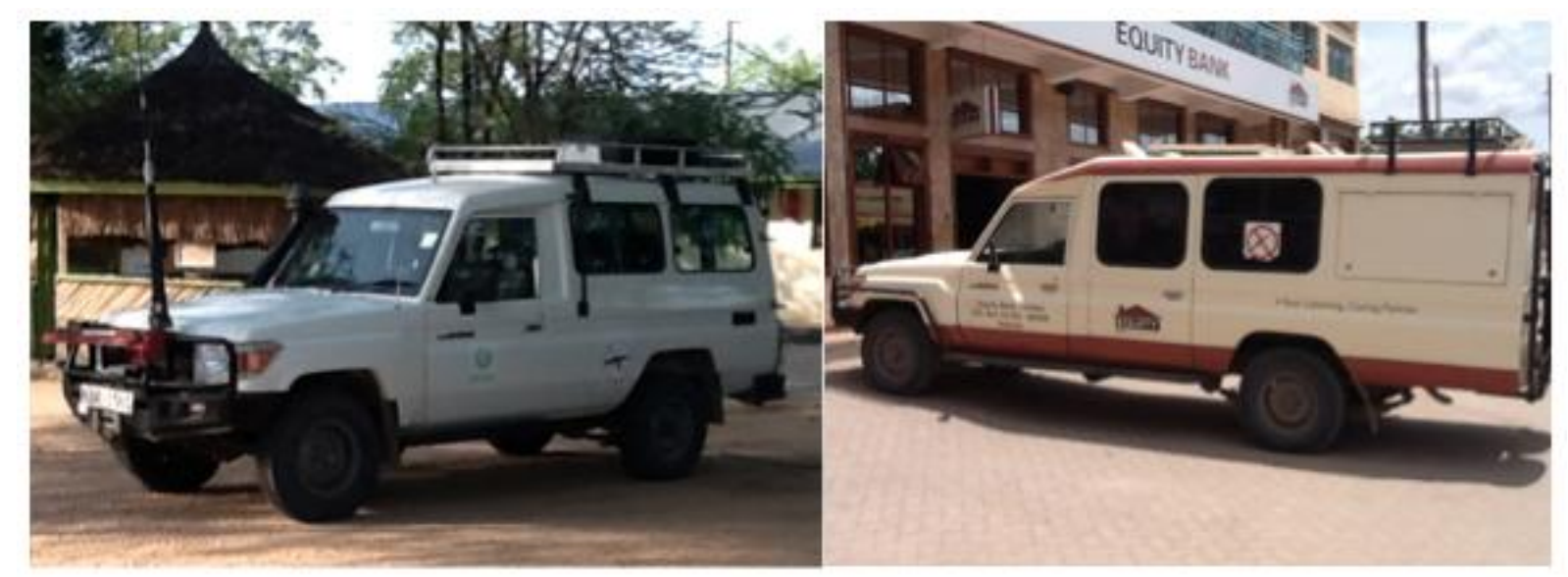

Figure 6. Both NGOs and Equity Bank rely on SUVs.

Because Land Cruisers are so reliable, the aid workers rarely considered them. More central to their concern was the information technology used to build the administrative and payment systems for the HSNP. While some worked smoothly - fading into the background as functioning infrastructure-others were deeply problematic. For example, from the end of 2012 to early 2013, the fingerprint scanners used to enroll beneficiaries repeatedly failed. For subsequent authentication, it is important that the initial biometric scan is of high quality, but the finely tuned scanners succumbed to a range of maladies. Dust and heat proved particularly fatal, and in January 2013 the failures had become so frequent and the delays so onerous that they had simply stopped registering fingerprints, and no one quite knew how they were going to fix the situation. Nor did they know what exactly caused the failures: while dust and heat were blamed, the complexities of the biometric devices, and the fact that they were bought from a foreign firm, meant no one in Nairobi-let alone Turkana-had the wherewithal to diagnose or solve the infrastructural breakdown.

Similar frustrations in the process of infrastructuring cash transfers arose from the computer software used to collect the personal details of the HSNP beneficiaries. In order to accurately pay the neediest, HSNP had developed a model known as the 'proxy means test' (PMT) that determines need and desert through an assessment of the number of dependencies, access to resources, and more. As one HSNP employee told me, the PMT algorithm makes calculable 
and commensurable "differences in socioeconomic [status]... because some people farm, some people fish, some people herd cattle. How do you come up with some sort of balance where you can say this person farms here is just as poor as this person who does fishing there?"32 The PMT was the means of doing so, but it, too, was trouble.



\section{Figure 7. HSNP enrolment in action.}

By April 2013, the software that managed the PMT was already on version 10.1. Each update represented a bug, error, or incongruence that necessitated a lengthy process of receiving an update from Nairobi that had to be transported the last distance on physical flash drives because telecommunications were too sparse. ${ }^{33}$ At times, this was a significant delay: from August to December work stalled due to a software glitch. For example, the software's designers had assumed monogamy in their survey although polygamy was not uncommon amongst the

\footnotetext{
${ }^{32}$ There are other modes of targeting beneficiaries, such as community voting or simply age (see Samson et al. 2011 for a discussion), and future work could fruitfully turn to the social and political implications of these rationalities.

33 The situation was even worse for the Orphan and Vulnerable Children program whose software was (for reasons unclear) developed and managed by a team in Colombia. As I was told, "every time you want to modify or make an upgrade, you have to go back to the developers, some firm in Colombia... It's amazing how difficult it is then just because the system, because you know, it affects everything. It affects payments, complaints and grievances; it affects everything. So the system has not been able to lodge complaints for instance. You know, you want to check the system to see, does it have the functionality to be able to do this? Well we need to go back to the developers in Colombia. Number one because they know their system. Even if they knew the system locally, it's in Spanish."
} 
Turkana. Similarly, it would not permit a 65 -year-old man to be listed as the father of a three-year-old son, though this, too, occurred. ${ }^{34}$

The Oxfam staff struggled against these meaningful tensions, attempting workarounds and tweaks. As active infrastructurers, they opportunistically relied on existing resources where possible. Because their computers would overheat in the mid-day sun, they worked in a thatch hut that was previously used to deposit food aid but had to reposition every few hours as the sun moved, blinding their camera used to take ID pictures. At the same time, a small solar panel converted the sun into an ally that powered their computers.

Throughout this, they needed to negotiate with the local populations, providing ad hoc solutions to their needs, such as allowing registration exceptions for women who needed to tend to their crops. Some beneficiaries were exasperated by the tedium of providing so much information. "If you're here to help," they told Oxfam, "just help." At times, beneficiaries subverted the plans of the HSNP representatives, leading to a sort of quiet contest as to who would control the emergence of the aid infrastructure. For example, as a result of the proxy means test, beneficiaries were assigned to one of four income brackets (very low, low, middle, and high). The aid workers had previously used an informal system of colored stickers on ID cards, with pink corresponding to very low, yellow to low, and so on. Although this was never disclosed to the grant recipients, they evidently recognized the pattern and soon enough Oxfam noticed that cards had been reshuffled, in contradiction to the dictates of the proxy means test. The quick fix that they adopted was to discard color-coding and instead use letters, with ' $\mathrm{TCW}$ ' indicating 'Turkana Central Wealthy. Literacy, then, became a tactic in infrastructural contests.

${ }^{34}$ Informant \#5. 


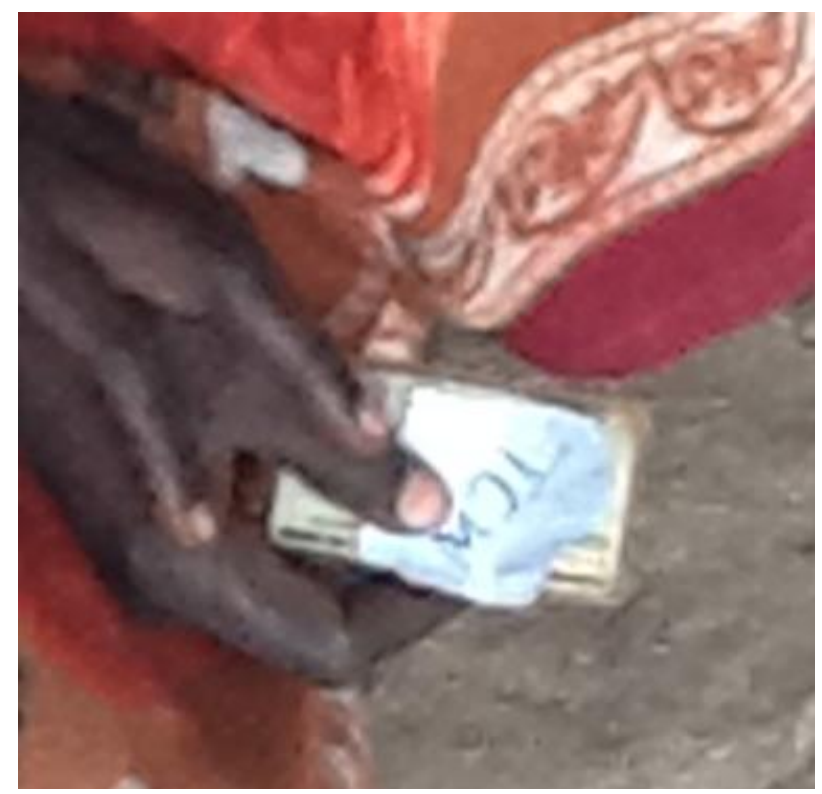

Figure 8. A woman holds her "TCW" slip.

\section{Agents}

After biometric identification, the second crucial means of infrastructuring cash transfers in northern Kenya was the system of agency banking, a practice of appointing local shopkeepers as cash dispersal entities. In early 2013, there were 52 Equity Bank-appointed agents in Turkana who served as the frontline of this humanitarian intervention. HSNP agents are small business-owners-often little more than a stall with some packaged food and drink - that verify beneficiaries by inserting their HSNP card and scanning their fingerprints on a specialized device. If the finger's ridges match the image on the card, then the agent hands over the cash with which the beneficiary is free to do as he or she pleases. As with a proliferating range of "humanitarian goods" (Redfield, 2012), the use of agents highlights the curious mix of public, private, and civil society actors who now constitute humanitarianism, an enormous global enterprise that Fassin (2007) characterizes as "nongovernmental government."

This model of incorporating local shopkeepers was pioneered for at least three direct reasons. First, by delegating responsibility to already existing entities, it reduces the upfront cost of deploying a payments infrastructure. HSNP does not need to establish facilities de novo. Because formal businesses are confined to the few population centers in Turkana, informal shops were the only existing infrastructure on which to build. Even today, "In the rural, the remote location, there is only the Equity agent." 35 If HSNP reflects a growing form of

\footnotetext{
${ }^{35}$ Informant \#3.
} 
transnational governance (Ferguson and Gupta, 2002), the street-level bureaucrats of tomorrow are likely to be private shopkeepers or NGO officials, not civil servants (cf. Lipsky, 1980).



\section{Figure 9. An Equity agent.}

Second, because agents are responsible for cash management, it limits the ongoing administrative burden to HSNP. On average, for every 1000-2000 beneficiaries, 4 to 5 agents are needed, each distributing millions of Kenyan shillings in the course of a payment cycle. This, in turn, permits a longer payments window that reduces waiting time and inconvenience. Finally, the combination of lower costs enables a much larger network of payment points to be established, assisting their goal of having an agent within 7 kilometers of all recipients. $^{36}$

At HSNP's inauguration, regulations from the Central Bank of Kenya did not allow non-banks to provide financial services. Such a rule is common in the prudential world of financial regulators, and required Equity Bank to acquire a special exemption to deputize would-be agents. Today, though, agency banking has grown enormously in Kenya and elsewhere through its use in mobile money,

\footnotetext{
${ }^{36}$ It is perhaps worth emphasizing that despite this highly capillary form of distribution, HSNP beneficiaries still need to be highly mobile to reach the agents. Although some HSNP officials were of the opinion that 7 kilometers is normal for pastoralists, others noted that if something went awry at the agent (such as a biometric device failure), it was a long distance there and back for naught.
} 
where agents are sometimes referred to as "human ATMs" (Maurer et al., 2013). This phrase is revealing for distilling what is the core purpose of the agents: cash provision. As with Latour's (1994) discussion of 'gunman' it also reveals the interlacing of both human and machine in the provision of cash. That is, the union of shopkeeper and biometric device is what allows this infrastructure to function.

For a range of reasons, a purely automated teller machine would not be feasible in Turkana where the necessary supporting infrastructures are absent. First, HSNP agents are responsible for acquiring the necessary cash to pay beneficiaries. Because bank branches are scant, this can involve considerable travel, but the shopkeepers already have the need and means to acquire cash for their businesses. Additionally, because serving as an agent implies a significant amount of new customers, the agents have a clear incentive to gather cash from afar. In programs that do not use agents - such as the OVC-I was told that centralized cash management is "a nightmare" requiring armored trucks, insurance, and logistics. ${ }^{37}$ Delegating the requirement onto properly incentivized entities removes this difficulty from the social protection program. Additionally, electricity is at best unreliable but more likely altogether absent. To surmount this challenge, payment devices are battery powered and recharged through solar panels that Equity provides on credit to the agents. HSNP's payment devices also function with intermittent telecommunications infrastructure: balancing and reconciling the accounts can occur whenever the agent is able to travel to a location with network coverage. This was necessary because at the beginning only 40 percent of Turkana had mobile network coverage. ${ }^{38}$

In addition to using agents to cope with infrastructural deficits, HSNP actively sought certain social, cultural, and interpersonal characteristics from their 'human ATMs'. Chief amongst these is trustworthiness: Equity does due diligence to ensure they are not selecting anyone nefarious, combing what formal records exist and querying the local community about the character of a would-be agent. Although the agents' profit interest is crucial to their enrolment, HSNP officials expressed a desire to avoid agents who were driven only by such a motivation.

\footnotetext{
${ }^{37}$ Informant \#15.

38 Although it has improved, mobile coverage is still limited, so HSNP is moving toward satellite connections in order to improve the real-time connection to agents. In part, this is motivated by financial regulations - written without Turkana in mind - that require real-time reconciliation for providers of full-service finance (a goal of Equity Bank for its currently special-purpose agents).
} 


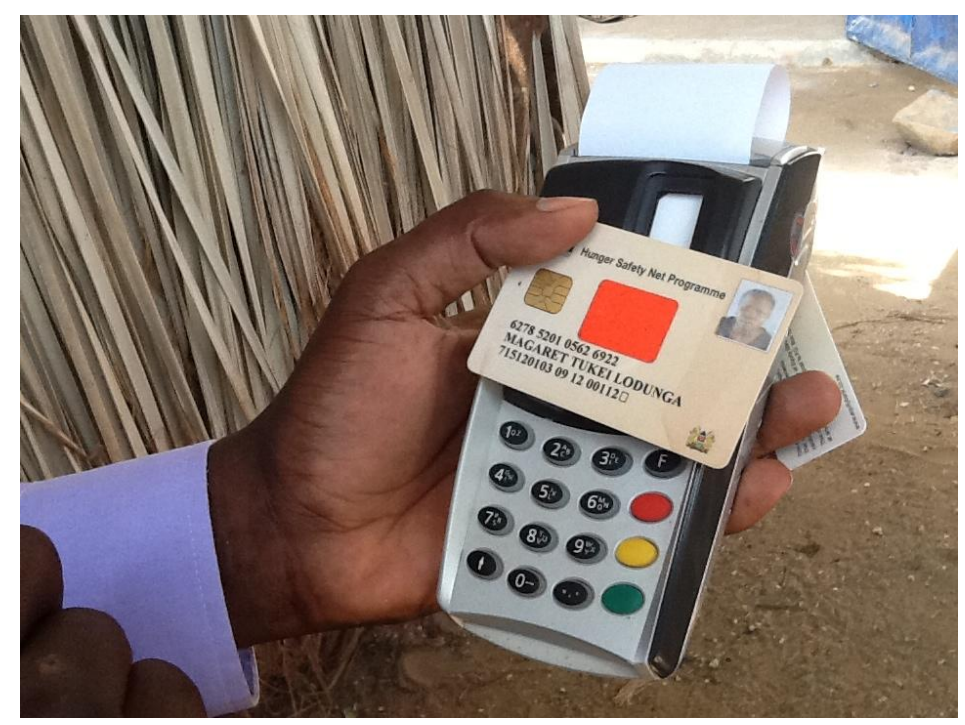

Figure 10. An HSNP / Equity biometric scanner.

They also need people with compassion and understanding of the needs of the recipients that a machine would be incapable of providing. As the head of Equity in Turkana told me, "We wanted an agent who would be a bit humane, treat them with dignity and be able to humble himself." 39 As such, they provide training to convey the humanitarian ethos of HSNP and the goals of the service. For example, entering the formal Equity Bank branch in Turkana can be intimidating: the whir of a generator, the marble facades, the glass partitions, and the bevy of technologies clearly set the space off from the rest of the locality (cf. Augé, 2009). A shopkeeper from the community is far more approachable.

The method has proven largely successful, with few complaints, even though there is the potential for agents to take advantage of the grant recipients. Only in one case was impropriety found to be occurring: when the grant was valued at KSh 2,250, a couple of agents began dropping the last KSh 250 (\$3) because of the difficulty providing such small denominations in such volume; instead, they offered free goods from their shop valued around KSh 250. When Equity learned of this, they disciplined or dropped the offending agents, explaining that "the [human] rights component is always there to check any malpractice and what have you. ${ }^{, 40}$ In this case, it was the pragmatics of actually existing money (the denominations and difficulty of creating change) that shaped behavior; it was only the regulative ideal of rights-based humanitarianism that corrected it. ${ }^{41}$

\footnotetext{
${ }^{39}$ Informant \#12.

${ }^{40}$ Informant \#12.

${ }^{41}$ On the pragmatics of money, see Maurer (2011) and Guyer (2004). I thank Taylor Nelms for his comments on this point.
} 


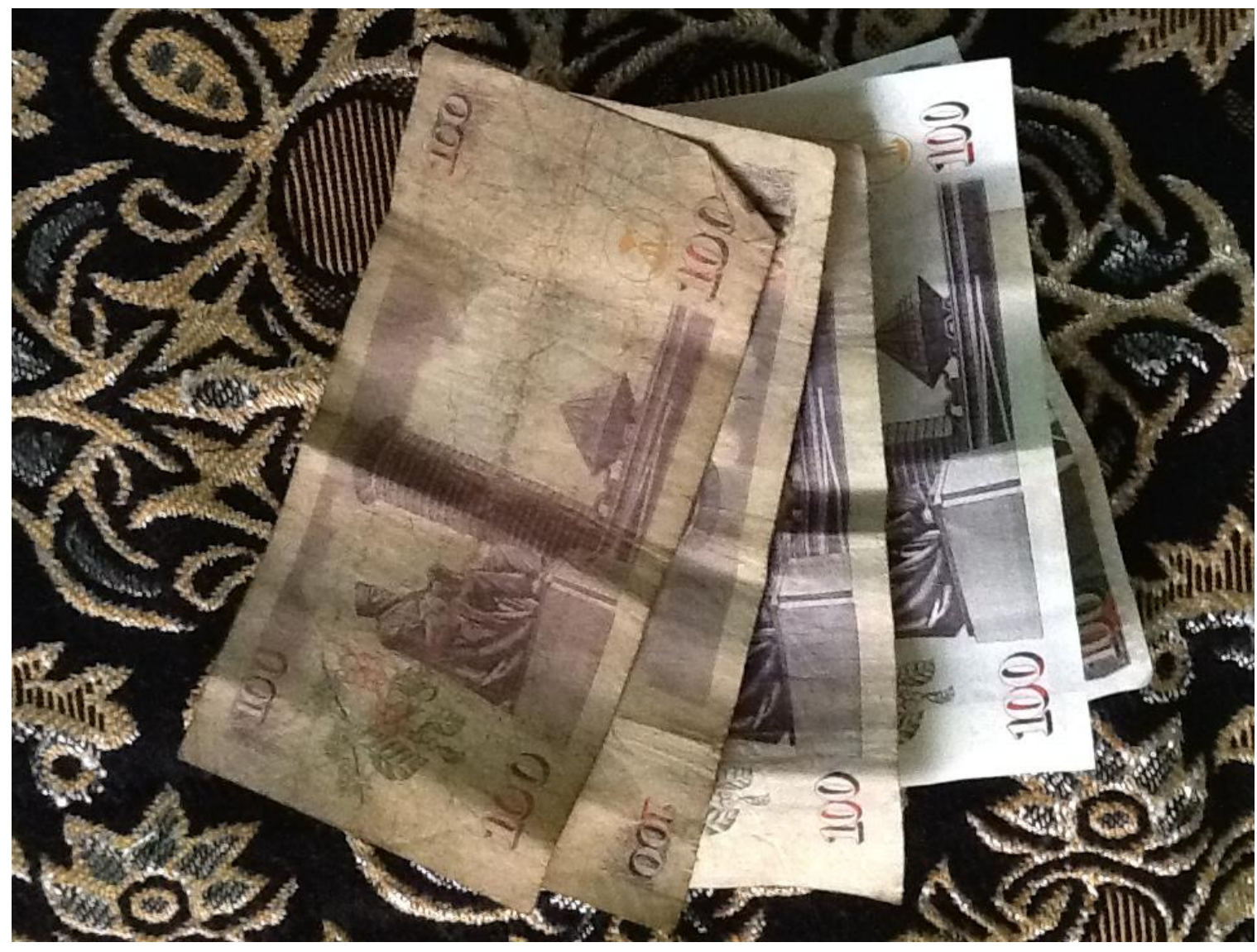

Figure 11. The materiality of money matters.

The use of agents illustrates a particular strategy of infrastructuring: delegation, meaning the exchange of human for technical labor (and vice versa) (Ribes et al., 2012). HSNP has delegated to both technologies and individuals, both with varying degrees of success. Agents are particularly interesting because they exhibit elements of both black-boxed technology and skillful humans. On the one hand, HSNP desires cash distributors who are objective, delivering money without inappropriate behavior such as fraud or theft. As one Equity official told me, the ideal agent is "somebody who will practice what we say." ${ }^{42}$ On the other hand, they want subjectivity, the sort of human touch that will assist with troubles when they arise. ${ }^{43}$ Of five payments I witnessed occurring, two of the fingerprint authentications originally failed; they succeeded only through the assistance of the payment agent who scrubbed the finger clean and placed it on the device correctly, cajoling human and machine to successfully interact (cf. Suchman, 2006).

\footnotetext{
${ }^{42}$ Informant \#12.

${ }^{43}$ The goal is transmission, but recognizing that certain transformations will be needed in order to do so; in the words of actor-network theory, 'intermediation' requires some 'mediation' (Callon, 1986; Latour, 1999). On objectivity more generally, see Daston and Galison (2007).
} 




Figure 12. Scanning an HSNP recipient.

Agents - in addition to other arts of infrastructuring discussed here-can be understood as a means of 'embedding' foreign practices into Turkana (cf. Ancelovici and Jenson, 2013). Following Giddens (1991), Takhteyev (2012) has discussed the type of practical work, tacit knowledge, and technical accommodation necessary to take a practice like cash transfers from one location to another:

"First, some elements of a practice-people, ideas, tools-must be dislodged from their original context, changed so as to become mobile. Such mobile elements then arrive in a new place, but do so as isolated pieces, disconnected from other elements that gave them power within the original system. To regain this power, they must be re-embedded - become a part of a local system... This usually means that elements brought from afar would need to be made to work with those of local origin, many of them repurposed or pulled out of extant systems. The resulting system will be an assemblage of ill-fitting parts "hacked together," to borrow a programmers' term."

Arguably this process of embedding infrastructure is made more difficult by the paucity of existing resources on which to build. Although the aid workers I 
observed were opportunistic, they could hardly create what Braun (1994) calls "second-order" infrastructures, meaning creating new infrastructures by recombining existing ones. Even where there was an "installed base" (Star, 1999) on which to build, such as shopkeepers, rules needed to be changed to permit their use as financial intermediaries. Far more common was the case of biometric identification: a technology novel in most of the world, let alone Turkana. The act of embedding it within the Turkana context required endless maneuvering, each with their own set of supporting practices. Solar panels could power the biometric devices at agents, but required extending credit to shopkeepers who could not purchase them outright. Tablet computers could acquire the necessary administrative data in bulk but required shade during the day and software updates to be carried to the field by flash drive. Identity cards could be acquired, but needed the cooperation of local bureaucrats as well as pockets in which to keep them.

Pull a single strand of the cash transfer infrastructural web and who knows how far it will go, yet given enough infrastructuring, circulation can occur, as cash does with a high degree of success in the Hunger Safety Net Program.

\section{Between Consumers and Citizens: The Politics of Infrastructuring Aid}

Cash transfers have risen to prominence within the humanitarian and development sector as a feasible means to alleviate poverty, reduce vulnerability, and meet other goals such as boosting health and education. The logic follows a quasi-Hayekian view of the poor as rational actors and markets as a means to effectively meet their needs (see Ferguson, 2010). Attention to the methods of cash delivery serve as a reminder of the labor and investment needed in order to create a market (Elyachar, 2012a). As Redfield (2012) notes for a range of new humanitarian interventions, this work is done through a curious mix of public, private, and non-profit entities.

As I have described, constructing a market is also a matter of everyday engineering. As recent social studies of finance have shown, embodiment and equipment matter to the types of markets that are created (MacKenzie, 2009; Callon, 1986). For those creating the HSNP infrastructure, manufacturing consumers was explicitly part of their understanding of their own work: "Pastoralists haven't been members of the national economy" before HSNP, I was told. And the particularities of the infrastructural designs would create different types of markets, such as those that excluded women without identity cards or elderly people unable to travel. 
In addition to creating consumers, infrastructuring here creates citizens. In this case, biometric technology is both a "market device" (Callon et al., 2007) but also what might be called a 'citizenship device'. For many of the HSNP officials, cash transfers were a way of incorporating remote Kenyans into the nation and were deeply ingrained with a rights-based mentality. This was most evident in the promotion of national identity documents, but also in the aspirations to build a more encompassing and durable welfare initiative.

As von Schnitzler (2013: 673) has recently explored in the South African case, infrastructures come "to mediate a diversity of competing ethical projects, political disagreements, and subterranean conflicts that often concern central political questions of civic virtue, basic needs, and the rights and obligations of citizenship." For example, Guldi (2012: 23) has documented how public access roads "enable the participation of poor people and poorer regions" and Maurer (2012b) argues in favor of state-backed money as a "public infrastructure", usable without "a toll on the means of value transfer."

In the case of HSNP, these infrastructural particularities became evident. Money affords a range of possibilities that food did not, including communal well digging and an increasing amount of formal savings accounts. In this way, HSNP created an infrastructure that "set in motion other types of flows that operate in the space capital provides and that travel the routes created by these new networks" (Larkin, 2004: 292). And the HSNP team had explicit aspirations to continue such second-order effects. For one, they would like to offer beneficiaries formal bank accounts, convinced of the developmental benefits of savings and other financial services. ${ }^{44}$ Here, basic needs were justified on humanitarian grounds and enacted through market devices. Throughout my fieldwork, although market means were pursued, they were embedded in an ethos and ethical regime of humanitarianism. As mentioned above, shopkeepers were castigated for violating "the rights component" of HSNP. Biometric scanners were adopted to meet beneficiary "dignity" and errors were fixed "on humanitarian grounds." While not carefully theorized or explicated, these discourses provided an ethical repertoire that shaped and was shaped by the act of infrastructuring. ${ }^{45}$

HSNP also had aspirations more recognizable as reflecting the rights of citizenship. One interesting plan that was taking shape in early 2013 is a plan to fund "one-stop human rights shops" where instead of just collecting complaints

\footnotetext{
${ }^{44}$ On the growth of 'financial inclusion' see Schwittay (2011), Roy (2010), and Manji (2010).

${ }^{45}$ As with other humanitarianism, expediency was crucial, and technical solutions were often pursued to the detriment of other considerations, most notably the privacy implications of a massive state-based registration scheme (see Hosein and Nyst, 2013). However, there were signs this was changing and a broader view of citizenship was emerging (see CaLP, 2013).
} 
and grievances about the program, HSNP infrastructure would be used to advocate on behalf of a broader range of rights violations in places like Turkana (cf. Moyn, 2012). This, of course, would be a high order (cf. Englund, 2006) but accorded with aspirations to leverage the seeming success of humanitarian cash transfers for more substantive initiatives, including ongoing plans to unify and institutionalize the five different cash transfers into a fledgling state-based welfare program (though largely donor funded) (cf. Ferguson, 2013). While the road to such a future would be long, the aspirations were already shaping infrastructural design in the present: through the aforementioned plan to enroll everyone in the arid and semi-arid lands, but also to combine these into a "single registry" with other cash transfers in Kenya, perhaps creating the administrative infrastructure of a welfare state. ${ }^{46}$

Despite all this, much of the actually existing infrastructure of humanitarianism in northern Kenya remained special-purpose and exclusive. SUVs sped past pastoral communities; biometric scanners remained the property of the program (and would hardly be useful otherwise). The aid workers I observed were, in large part, interested in making the technology disappear and fade into the background. They did not want their infrastructure to be open to contestation, but rather simply to work (cf. Ferguson, 1994). A focus on solving narrowly defined problems (i.e. a paucity of cash) has contributed to the "minimalist biopolitics" that Redfield (2012) says characterize humanitarianism. Fostering life, yes, but in a constrained and particular manner.

\section{Conclusion}

The various tactics taken in establishing cash transfers in locations like Turkana encourage the conceptualization of "infrastructure as a transitive verb" (Edwards et al., 2009: 370). Thinking along the lines of 'establishing the infrastructure' is misleading, both because it is never finished and because it always remains tenuous: a change of donor heart in London could cripple the infrastructure.

As those operating cash transfer programs are quick to acknowledge, the means of registering and paying beneficiaries are crucial infrastructural challenges. This is a particular challenge given the paucity of existing infrastructure, especially in the rural areas where poverty and food insecurity are often most challenging. As I have sought to illustrate, creating a (largely) functional cash transfer infrastructure requires far more than installing "leapfrog technology" (cf. Garcia and Moore, 2012: 7).

\footnotetext{
${ }^{46}$ On this relationship between registration and welfare, see Szreter and Breckenridge (2012).
} 
Creating the means to circulate monetary value in areas largely disconnected from the global financial infrastructure requires a combination of social and material efforts. What results is opportunistic, delicate, and unwieldy, but also clever, largely functional, and novel. It is a true bricolage. Infrastructuring aid, as I have argued in this case requires bodies and trucks, negotiations and trust, telecom towers and solar rays. But we could do more to encourage a less minimalist approach, an imaginative shift from humanitarianism to infrastructure that is widely enabling. 


\section{References}

AICD. 2010. Kenya's Infrastructure: A Continental Perspective. Washington, D.C.: World Bank.

Akrich, M. 1992. "The De-Scription of Technical Objects," in W.E. Bijker and J. Law (eds.) Shaping Technology/Building Society: Studies in Sociotechnical Change. Cambridge: MIT Press.

Ancelovici, M. \& J. Jenson. 2013. Standardization for Traditional Diffusion: The Case of Truth Commissions and Conditional Cash Transfers. International Journal Political Sociology, 7(3): 294-312.

Anand, N. 2011. Pressure: The politechnics of water supply in Mumbai. Cultural Anthropology, 26(4), 542-564.

Augé, M. 2009. Non-Places: An Introduction to Supermodernity. London: Verso.

Barker J. 2005. "Engineers and political dreams: Indonesia in the satellite age." Current Anthropology, 46(5): 703-27.

Bowker, G.C. 1994. Science on the Run: Information Management and Industrial Geophysics at Schlumberger; 1920-1940. Cambridge, MA: MIT Press.

Braun, I. 1994. Geflügelte Saurier: zur intersystemische vernetzung grosser technische Netze. In Braun, I. and B. Joerges (eds.) Technik ohne Grenzen. Frankfurt am Main: Suhrkamp.

Callon, M. 1986. Some elements of a sociology of translation: domestication of the scallops and the fisherman of St Brieuc Bay. In Law, J. (ed.) Power, Action, and Belief: A New Sociology of Knowledge? London: Routledge.

Callon, M. 1999. The Laws of the Markets. London: Routledge.

Callon, M., Millo, Y. \& F. Muniesa. 2007. Market Devices. London: WileyBlackwell.

CaLP. 2013. Protecting Beneficary Privacy: Principles and operational standards for the secure use of personal data in cash and e-transfer programmes. Oxford: The Cash Learning Project. 
Cole, S. 2006. Is Fingerprint Identification Valid? Rhetorics of Reliability in Fingerprint Proponents Discourse. Law \& Policy, 28(1), 109-135.

Collier, S.J. 2011. Post-Soviet social: neoliberalism, social modernity, biopolitics. Princeton, NJ: Princeton University Press.

Daston, L. \& P. Galison, P. 2007. Objectivity. Cambridge: Zone Books.

Donovan, K.P. 2012. "Mobile Money for Financial Inclusion: Growth, Impact and Emerging Issues." Information \& Communication for Development 2012. Washington, D.C.: World Bank.

Donovan, K.P. 2013. "The Biometric Imaginary: Standardization and Objectivity in Post-Apartheid Welfare." UCT Centre for Social Science Research Working Paper no. 335. Cape Town.

Dourish, P. \& G. Bell. 2007. The infrastructure of experience and the experience of infrastructure: meaning and structure in everyday encounters with space. Environment and Planning B Planning and Design, 34(3), 414.

Dreze, J. \& A. Sen. 1991. Hunger and Public Action. Oxford: Oxford UP.

Edwards, P.N. 2003. "Infrastructure and modernity: Force, time, and social organization in the history of sociotechnical systems." In Brey, P., Rip, A. \& A. Feenberg (eds.) Technology \& Modernity: The Empirical Turn. Cambridge, MA: MIT Press.

Edwards, P.N. 2010. A Vast Machine: Computer Models, Climate Data, and the Politics of Global Warming. Cambridge, MA: MIT Press.

Edwards, P.N., Jackson, S.J., Bowker, G.C., \& C.P. Knobel. 2007. Understanding Infrastructure: Dynamics, Tensions, and Design. Available at: http://pne.people.si.umich.edu/PDF/ui.pdf

Edwards, P.N., Bowker, G.C., Jackson, S.J., \& R. Williams. 2009. Introduction: An Agenda for Infrastructure Studies. Journal of the Association for Information Systems, 10: 364-374.

Elyachar, J. 2010. Phatic labor, infrastructure, and the question of empowerment in Cairo. American Ethnologist, 37(3): 452-464. 
Elyachar, J. 2012a. Before (and After) Neoliberalism: Tacit Knowledge, Secrets of the Trade, and the Public Sector in Egypt. Cultural Anthropology, 27(1), 7696.

Elyachar, J. 2012b. Next Practices: Knowledge, Infrastructure, and Public Goods at the Bottom of the Pyramid. Public Culture, 24(1): 109-129.

Englund, H. 2006. Prisoners of Freedom: human rights and the African poor. Berkeley: University of California Press.

Fassin, D. 2007. "Humanitarianism: a nongovernmental government." In Feher, M. (ed.) Nongovernmental Politics. Cambridge: Zone Books.

Ferguson, J. 1994. The anti-politics machine. Minneapolis: University of Minnesota Press.

Ferguson, J. 2010. The uses of neoliberalism. Antipode, 41(s1), 166-184.

Ferguson, J. 2013. Declarations of dependence: labour, personhood, and welfare in southern Africa. Journal of the Royal Anthropological Institute, 19(2), 223242.

Ferguson, J. \& A. Gupta. 2002. "Spatializing States: Toward an Ethnography of Neoliberal Governmentality." American Ethnologist 29(4): 981-1002.

Foster, V. \& C. Briceño-Garmendia. 2010. Africa's Infrastructure: A Time for Transformation. Washington, D.C.: The World Bank.

Garcia, M. \& C.M.T. Moore. 2012. The Cash Dividend: The Rise of Cash Transfers in Sub-Saharan Africa. Washington, D.C.: World Bank.

Giddens, A. 1991. The Consequences of Modernity. London: Polity.

Gilligan, D.O., Hoddinott, J., Kumar, N.R, Taffesse, A.S, Dejene, S., Gezahegn, F. \& Y. Yohannes. 2009. Ethiopia Food Security Program: Report on 2008 Survey. Washington, D.C.: International Food Policy Research Institute.

Graham, S. \& S. Marvin. 1996. Telecommunications and the City: Electronic Spaces, Urban Places. London: Routledge.

Graham, S. \& S. Marvin. 2001. Splintering Urbanism: Networked Infrastructures, Technological Mobilities and the Urban Condition. London: Routledge. 
Guldi, J. 2012. Roads to Power: Britain Invents the Infrastructure State. Cambridge, MA: Harvard University Press.

Guyer, J. 2004. Marginal Gains: Monetary Transactions in Atlantic Africa. Chicago: University of Chicago Press.

Hanlon, J., Barrientos, A. \& D. Hulme. 2010. Just give money to the poor: The development revolution from the global South. Sterling, VA: Kumarian Press.

Hosein, G. \& C. Nyst, C. 2013. Aiding Surveillance: An exploration of how development and humanitarian aid initiatives are enabling surveillance in developing countries. London: Privacy International.

Hughes, T. 1993. Networks of Power: Electrification in Western Society, 18801930. Baltimore, MA: John Hopkins University Press.

Hull, M. 2012. Government of Paper: The Materiality of Bureaucracy in Urban Pakistan. Berkeley, CA: University of California Press.

Humphrey, C. 2005. "Ideology in infrastructure: architecture and Soviet imagination. Journal of the Royal Anthropological Institute, 11(1): 39-58.

Jackson, S.J. 2014. Rethinking Repair. In Gillespie, T., Boczkowski, P. \& K. Foot (eds.) Media Technologies: Essays on Communication, Materiality and Society. Cambridge, MA: MIT Press.

Jensen, C.B. \& B.R. Wintheriek. 2013. Monitoring Movements in Development Aid: Recursive Partnerships and Infrastructures. Cambridge, MA: MIT Press.

Johnson, D. 2008. Case Study on the Use of Smartcards to Deliver Government Benefits in Andhra Pradesh, India. Institute for Financial Management and Research. Available at: http://ssrn.com/abstract=1886014

Larkin, B. 2004. Degraded Images, Distorted Sounds: Nigerian Video and the Infrastructure of Piracy. Public Culture, 16(2): 289-314.

Larkin, B. 2008. Signal and noise: media, infrastructure, and urban culture in Nigeria. Durham, NC: Duke University Press.

Larkin, B. 2013. "The Politics and Poetics of Infrastructure." Annual Review of Anthropology, 42: 327-43. 
Latour, B. 1994. On Technical Mediation-Philosophy, Sociology, Genealogy. Common Knowledge, 3(2): 29-64.

Latour, B. 1999. When Things Strike Back: A Possible Contribution of Science Studies to the Social Sciences. British Journal of Sociology, 51(1): 105-123.

Lipsky, M. 1980. Street-Level Bureaucracy: Dilemmas of the Individual in Public Services. New York: Russell Sage Foundation.

Lyon, D. (ed.) 2003. Surveillance as Social Sorting: Privacy, Risk and Automated Discrimination. London: Routledge.

MacKenzie, D. 2009. Material Markets: How Economic Agents are Constructed. Oxford: Oxford UP.

Magnet, S. 2011. When Biometrics Fail: Race, Gender, and Technology of Identity. Durham, NC: Duke University Press.

Manji, A. 2010. 'Eliminating poverty? ' Financial inclusion', access to land, and gender equality in international development." The Modern Law Review, 73(6): 985-1004.

Mas, I. 2012. My PIN is 4321. CGAP Blog. Available at: http://www.cgap.org/blog/my-pin-4321

Maurer, B. 2011. Mobile money, money magic, purse limits, and pins: tracing monetary pragmatics. Journal of Cultural Economy, 4(3): 349-359.

Maurer, B. 2012a. Mobile Money: Communication, Consumption and Change in the Payments Space. Journal of Development Studies, 48(5): 589-604.

Maurer, B. 2012b. Payment: forms and functions of value transfer in contemporary society. Cambridge Anthropology, 30(2), 15-35.

Maurer, B., Nelms, T.C., \& S.C. Rea. 2013. 'Bridges to cash': channeling agency in mobile money. Journal of the Royal Anthropological Institute, 19(1), $52-74$.

Mitchell, T. 2011. Carbon Democracy: Political Power in the Age of Oil. New York: Verso.

Mosse, D. 2004. Cultivating Development: An Ethnography of Aid Policy and Practice. London: Pluto Press. 
Moyn, S. 2012. The Last Utopia: Human Rights in History. Cambridge, MA: Belknap Press.

Pipek, V. \& V. Wulf. 2009. "Infrastructuring: Towards an Integrated Perspective on Design and Use of Information Technology." Journal of the Association of Information Systems, 10(5): 306-332.

Porteous, D. 2009. Designing and Implementing Financially Inclusive Payment Arrangements for Social Transfer Programmes. London: DfID.

Power, M. 1997. The Audit Society: Rituals of Verification. Oxford: Oxford University Press.

Redfield, P. 2012. "Bioexpectations: Life Technologies as Humanitarian Goods." Public Culture, 24(1): 157-184.

Redfield, P. 2013. Life in Crisis: The Ethical Journey of Doctors without Borders. Berkeley, CA: University of California Press.

Ribes, D. \& K.S. Baker. 2006. 'Elements of Social Science Engagement in Information Infrastructure Design', ACM: The Proceedings of the 7th Annual International Conference on Digital Government Research, San Diego, CA, May 21-24.

Ribes, D., Jackson, S.J., Geiger, R.S., Burton, M. \& T. Finholt. 2012. Artifacts that organize: Delegation in the distributed organization. Information and Organization, 23(1): 1-14.

Rottenburg, R. 2009. Far-Fetched Facts: A Parable of Development Aid-Inside Technology. Cambridge, MA: The MIT Press.

Roy, A. 2010. Poverty Capital: Microfinance and the Making of Development. New York: Routledge.

Samson, M., van Nieker, I., \& K. Mac Quene. 2011. Designing and Implementing Social Transfer Programmes ( $2^{\text {nd }}$ edition). Cape Town: EPRI.

Schwittay, A. F. 2011. The financial inclusion assemblage: subjects, technics, rationalities. Critique of Anthropology, 31(4): 381-401. 
Seekings, J. 2008. 'Deserving individuals and groups: the post-apartheid state's justification of the shape of South Africa's system of social assistance.' Transformation, 68.

Setel, P., MacFarlane, S., Szreter, S., Mikkelsen, L., Jha, P., Stour, S. \& C. AbouZahr. 2007. "A scandal of invisibility: making everyone count by counting everyone." The Lancet, 37(9598): 1569-1577.

Smirl, L. \& B. Lister. 2010. Drive-By Development: Thinking Through the Sports Utility Vehicle in Humanitarian Assistance. Available at: http://backdoorbroadcasting.net/2010/12/lisa-smirl-and-beth-lister-drive-bydevelopment-thinking-through-the-sports-utility-vehicle-in-humanitarianassistance/

Sneath, D., Holbraad, M. \& M.A. Pedersen. 2009. "Technologies of the imagination: an introduction." Ethnos, 74(1): 5-30

GoK. 2012. Kenya Social Protection Sector Review. Nairobi. Available at: http://www.vision2030.go.ke/cms/vds/Kenya_Social_Protection_Review_Final. $\underline{\mathrm{pdf}}$

Star, S.L. 1991. Power, technologies and the phenomenology of conventions: On being allergic to onions. In Law, J. (ed.) A Sociology of Monsters: Essays on Power, Technology \& Domination. London: Routledge.

Star, S.L. 1999. The ethnography of infrastructure. American behavioral scientist, 43(3): 377-391.

Suchman, L. 2006. Human-Machine Reconfigurations: Plans and Situated Actions. Cambridge, MA: Cambridge University Press.

Szreter, S. \& K. Breckenridge. 2012. 'Editor's Introduction: Recognition and Registration: The Infrastructure of Personhood in World History.' In Breckenridge, K. \& S. Szreter (eds.) Registration and Recognition: Documenting the Person in World History. Oxford: Oxford University Press.

Takhteyev, Y. 2012. Coding Places: Software Practice in a South American City. Cambridge, MA: MIT Press.

Van der Ploeg, I. 2002. 'Biometrics and the body as information: normative issues of the socio-technical coding of the body.' In Lyon, D. (ed.) Surveillance as Social Sorting: Privacy Risk, and Digital Discrimination. London: Routledge. 
Von Schnitzler, A. 2008. Citizenship Prepaid: Water, Calculability and TechnoPolitics in South Africa. Journal of Southern African Studies, 34(4): 899-917.

Von Schnitzler, A. 2013. Traveling Technologies: Infrastructures, Ethical Regimes, and the Materiality of Politics in South Africa. Cultural Anthropology, 28(4): 670-693. 